\title{
Protozoan Diseases in Farm Ruminants
}

\author{
Sima Sahinduran \\ University of Mehmet Akif Ersoy, \\ Faculty of Veterinary Medicine, \\ Department of Internal Medicine, \\ Turkey
}

\section{Introduction}

Protozoa are ubiquitous throughout aqueous environments and the soil, and play an important role in their ecology. Protozoa occupy a range of trophic levels. They also play a vital role in controlling bacteria population and biomass. Farm animals are usually infected with several species of parasites and they are also confined to pasture or pens. Parasite eggs, larvae, and cysts are intense in soil. One of the most important aspect of animal protozoology is transmission to humans. These are called zoonosis. Some of zoonotic diseases are common and important to public health. This chapter is about of the etiology, epidemiology, pathogenesis, clinical findings, diagnosis, treatment and control of the pathogenic protozoa in farm ruminants.

\section{Babesiosis}

\subsection{Etiology}

Babesiosis is an infectious tick- borne disease of livestock that characterised by fever, anemia, haemoglobinuria and weakness. The disease also is Known by such names as bovine babesiosis, piroplasmosis, Texas fever, redwater, tick fever, and tristeza (Zaugg, 2009). The disease also is a hemoparasitic disease caused by protozoa of the genus Babesia (Phylum: Apicomplexa), which infects mainly ruminants (Melendez, 2000). Infection of a vertebrate host is initiated by inoculation of sporozoite form of parasites into the blood stream during the taking of a blood meal (Radostits et al. 2008). The list of babesia species is shown in table 1.

\subsection{Epidemiology}

\subsubsection{Bovine babesiosis}

Bovine babesiosis disease is caused by at least six Babesia species (Table 1). Bovine babesiosis associated with $\mathrm{B}$. bigemina and B. bovis is the most important disease of tropical and subtropical regions between $40^{\circ} \mathrm{N}$ and $32^{\circ} \mathrm{S}$. Both species are transmitted transovarially by Boophilus ticks, but only tick larvae transmit B. bovis, whereas nymphs and adults transmit B. bigemina. (Radostits et al. 2008). In Europe, babesiosis is caused by Babesia divergens, an intraerythrocytic parasite that can persist for $>13$ months in the organs of 
infected cattle. The distribution of B. divergens reflects its triphasic telotropic tick vector, Ixodes ricinus, which is widespread across Western Europe and North Africa (Jammes, 2009). B. major occur in Europe, North Africa and South America. B. major is transmitted by the three host tick Haemaphysalis punctata ( Taylor et al., 2007).

\begin{tabular}{|l|l|l|}
\hline Organism & Livestock affected & Geographic distribution \\
\hline B. bigemina & Cattle & $\begin{array}{l}\text { Americas, Europe, Africa, } \\
\text { Australia, Middle East }\end{array}$ \\
\hline $\begin{array}{l}\text { B. bovis (B. berbera, B. } \\
\text { argentina) }\end{array}$ & Cattle & $\begin{array}{l}\text { Americas, Europe, Russia, } \\
\text { Africa, Asia Australia }\end{array}$ \\
\hline B. divergens & Cattle & Europe \\
\hline B. major & Cattle & $\begin{array}{l}\text { Europe, Russia, North } \\
\text { Africa, Middle East }\end{array}$ \\
\hline B. jakimovi & Cattle & Asia \\
\hline B. ovata & Cattle & Japan \\
\hline B. motasi & Sheep and goats & $\begin{array}{l}\text { Southern Europe, Russia, } \\
\text { southest Asia, Middle East, } \\
\text { Africa }\end{array}$ \\
\hline B. ovis & $\begin{array}{l}\text { Southern Europe, Russia, } \\
\text { Asia, Middle East }\end{array}$ \\
\hline
\end{tabular}

Table 1. Babesia species (Babesiosis)

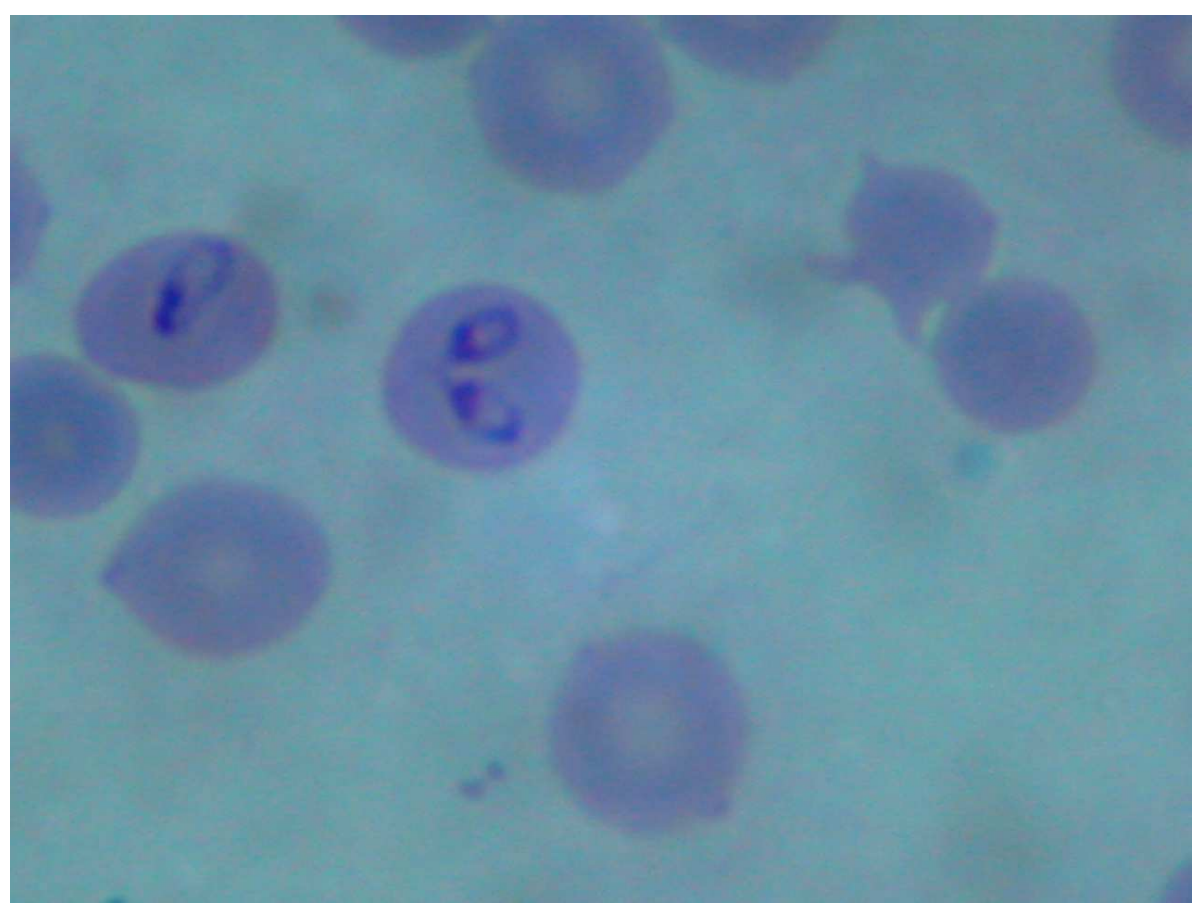

Fig. 1. Babesia bigemina in blood smear from a cow, Giemsa staining, immersion objective 


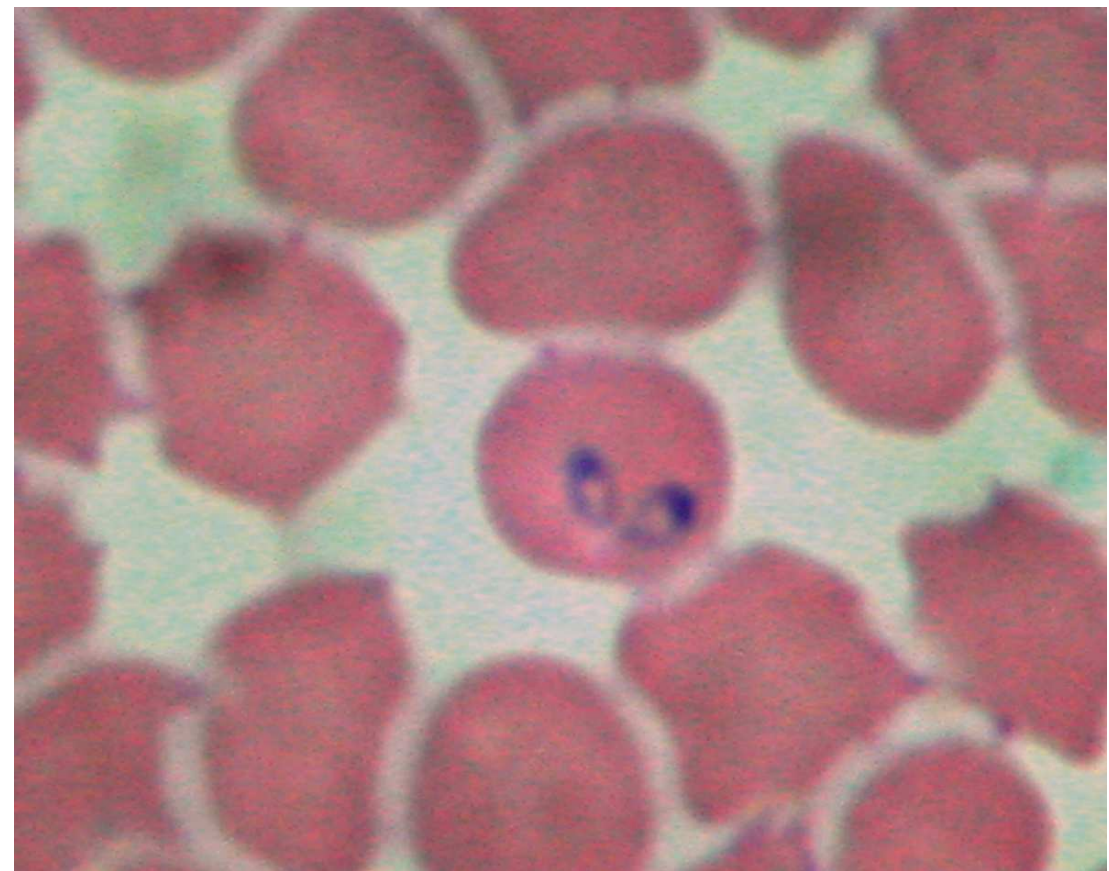

Fig. 2. B. bovis in blood smear from a cow, Giemsa staining, immersion objectiv

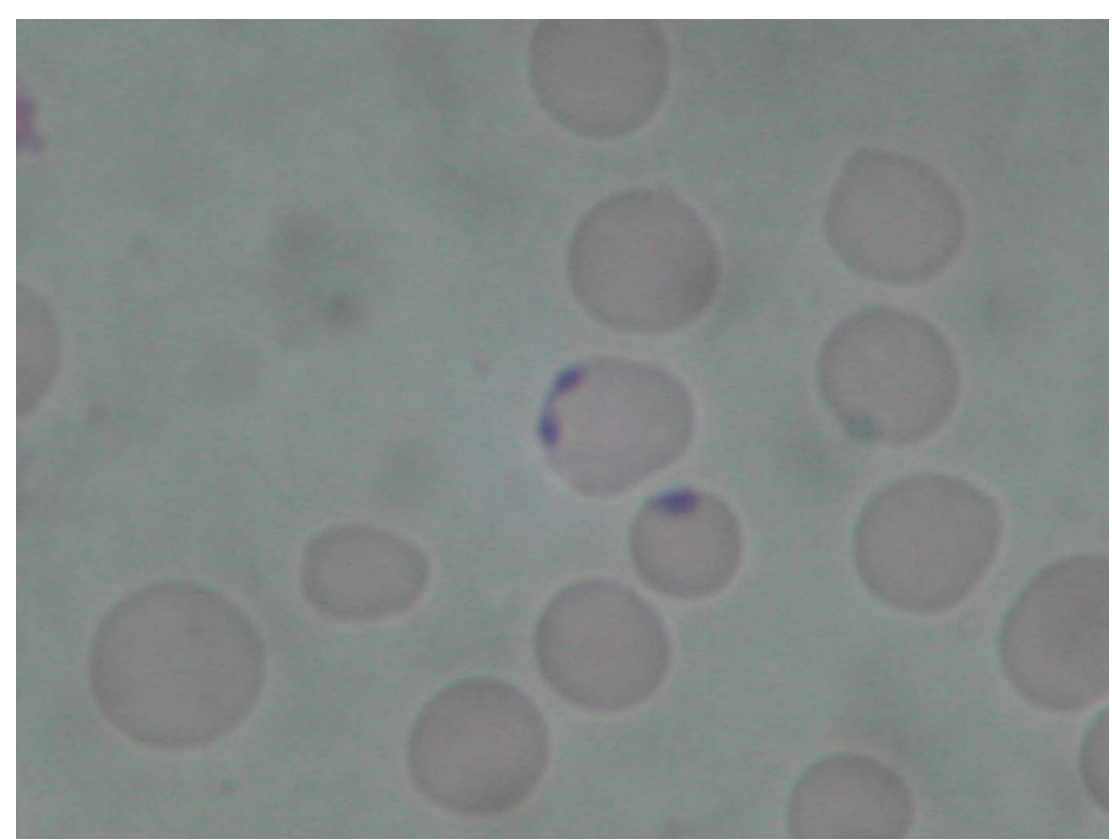

Fig. 3. B. divergens in blood smear from a cow, Giemsa staining, immersion objective 


\subsubsection{Sheep and goats}

In sheep and goats, babesiosis is associated with B. ovis and B. motası. Babesia ovis occur in Southern Europe, former Soviet State, Middle East and Asia. Rhipicephalus bursa has been shown to be a vector for B. ovis. Babesia motasi occur in Southern Europe, the Middle East, the former Soviet State, southeast Asia and Africa. The parasite transmitted by ticks of the genus Haemaphysalis (H. Punctata, H. Otophila), Dermacentor (D. silvarum) and Rhipicephalus (R. Bursa)( Taylor et al., 2007).

\subsection{Pathogenesis}

Babesia spp. are a various group of tickborne, obligate, intra-erythrocytic Apicomplexan parasites infecting a wide variety of animals. Ticks are most often infected transovarially. The female tick becomes infected by the ingestion of parasites during engorgement. After it drops off the host, the babesial agents reproduce within the tick's tissues. Some of the reproducing organisms are incorporated within developing tick embryos, and the disease agents are transmitted to new hosts by the feding of ensuing tick larvae, nymphs, or adults (Zaugg, 2009).

B. bovis is the most pathogenic of the bovine Babesia. B. bigemina infections are not as virulent as those of B. bovis, however the parasites may infect $40 \%$ of the red cells (Taylor et al., 2007).

Babesia affecting small ruminants are generally less pathogenic than their bovine likes (Cebra, C., and Cebra, M., 2002a).

\subsection{Clinical findings}

\subsubsection{Cattle}

Incubation period is 2-3 weeks. B. bigemina and B. bovis produce acute syndromes which are clinically indistinguishable, and are characterized by high fever $\left(41^{\circ} \mathrm{C}\right)$, anorexia, depression, weakness, cessation of rumination, and a fall in milk yield. Hemoglobinuria can be seen, the color of urine is dark-red to brown. Respiratory and heart rates are increased, and the red conjunctivate and mucous membranes change to the extreme pallor of severe anemia. Abortion ocur in pregnant animals (Radostits et al., 2000). Subacute syndrome also occurs in young animals, but fever is mild and hemoglobinuria is absent (Radostits et al., 2008).

In cerebral babesiosis, hyperexcitability, convulsions, opisthotonos, coma, and death, may be observed in cattle infected with either B. bigemina or B. bovis, but especially with the B. bovis. Central nervous system signs are caused by brain anoxia resulting from severe anemia (Zaugg, 2009).

\subsubsection{Sheep}

In sheep develop fever and parasitemia within 2 to 4 days; the clinical signs of the disease include anorexia, listlessness, anemia, moderate jaundice and hemoglobinuria. In intact animals, hyperthermia returned to normal on the fourth day after the peak pyrexia, and parasitemia is eliminated within the course of the disease (Rahbari et al., 2008). 


\subsection{Diagnosis}

Blood smears and clinical findingd are useful in acute cases of piroplasmosis, but are not sufficient in subclinical cases. The complement fixation test is used serological test for bovine babesiosis. The most commonly used tests are ELISA, PCR and a DNA probe, which can detect specific parasitemias at very low levels of infection (Radostits, 2008). Recently, the 'reverse line blot (RLB) is a versatile technique for simultaneous detection and identification of small ruminant piroplasm species, based on the recognition of specific gene regions by oligonucleotide probes (Nagore et al., 2004; Qingli et al., 2009; Inci et al., 2010;).

\subsection{Treatment and control}

After the hemoglobinuria or cerebral signs, prognosis is not well. In acute cases that PVC values are above $12 \%$, treatment will be successful. Supportive therapy such as blood transfusions (4 L of whole blood per $250 \mathrm{~kg}$ of body weight), fluids, hematinics, and prophylactic antibiotics are important (Zaugg, 2009). Babesiosis can be treated using diminazene aceturate $(3-5 \mathrm{mg} / \mathrm{kg})$, phenemidine diisethionate $(8-13 \mathrm{mg} / \mathrm{kg})$, imidocarb dipropionate (1-3 mg/kg), and amicarbalide diisethionate (5-10 mg / kg) (Cebra, C., and Cebra, M., 2002a; Taylor, 2007; Radostits, 2008; Zaugg, 2009).

The control of the disease depends on effective quarantine to prevent the introduction of the vector tick. The control of ticks by dipping or spraying animals at risk with recommended acaricides. In routine surgery, Care should be taken to prevent accidental transfer of blood from one animal to another (e.g., castration, dehorning). In addition, in cattle, the selection and breeding of cattle which acquire a high degree of resistance to ticks is practiced. Widespread use of tick vaccines may also have a significant influence on the incidence of infection in cattle (Taylor et al., 2007; Radostits et al., 2008; Zaugg, 2009).

\section{Theileriosis}

\subsection{Etiology}

Theileriosis is caused by Theileria spp. in cattle, goats, sheep and wild and captive ungulates (Radostits et al., 2000). Theileriosis is a hemoparasitic disease caused by protozoa of the genus Theileria (Apicomplexa). Theileria species affect domestic and wild ruminants, especially in Africa, Europe, Australia, and Asia (Allison and Meinkoth, 2010). The parasites are transmitted by tick. These parasites, undergo repeated merogony in the lymphocytes ultimately releasing small merozoites, which invade the red cells to become piroplasms. Theileriosis, have a variety of tick vectors which cause infections ranged from clinically inapparent to rapidly fatal (Taylor et al., 2007).

The list of theileria species is shown in table 2.

\subsection{Epidemiology}

\subsubsection{Bovine theileriosis}

Bovine theileriosis is caused by at least six Theileria species (Table 2). In bovine, East coast fever caused by T. parva. The tick vector is Rhipicephalus appendiculatus. East coast fever generally ocur in cattle but also buffalo (OIE., 2004), and occurs in East Africa. ECF is prevalent throughout the wetter areas, but is absent from the wet highlands in the horn of 
Africa (Norval et al., 1991). In Africa, T. parva is a highly fatal disease in cattle (Lawrence et al., 2004; Carlson, 2009a) and this disease is a great threat on the development of the livestock industry, with losses of about 10,000 cattle per year in Zambia (Nambota et al., 1994).

\begin{tabular}{|l|l|l|}
\hline Organism & Livestock affected & Geographic distribution \\
\hline T. parva & Cattle, African buffalo & East and central Africa \\
\hline T. annulata & Cattle, domestic buffalo & $\begin{array}{l}\text { Mediterranean countries } \\
\text { (Portugal and Spain, the } \\
\text { Balkans), Middle East, } \\
\text { Indian subcontinent and } \\
\text { China }\end{array}$ \\
\hline T. orientalis complex & Cattle & $\begin{array}{l}\text { Southern Europe, Middle } \\
\text { East, Asia, Australia }\end{array}$ \\
\hline T. velifera & Cattle, zebu & Africa \\
\hline T. taurotragi & Cattle, antelope, \\
particularly the eland & Africa \\
\hline T. mutans & Cattle, deer & Africa, Caribbean Islands \\
\hline T. hirci & Sheep and goats & $\begin{array}{l}\text { North and East Africa, } \\
\text { Middle East, India }\end{array}$ \\
\hline T. ovis & Sheep and goats & Europe, Africa, India \\
\hline
\end{tabular}

Table 2. Theileia species (Theileriosis)

In bovine, Tropical Theileriosis (Mediterranean coast fever), occurs in Mediterranean countries, Middle East, Indian and China, and is caused by T. annulata (Radostits et al., 2008). The tick vectors are Hyalomma dentritum in north Africa and in the Mediterranean countries, H. dentritum and H. dromedaii in central Asia, and H. marginatum in India ( Taylor et al., 2007; Radostits et al., 2008). In endemic areas indigenous cattle are relatively resistant while modified cattle, especially European breeds, are highly susceptible (Taylor et al., 2007).

Theileria orientalis complex is a milder disease than East coast fever and Tropical Theileriosis, and called benign theileriosis in cattle (Radostits et al., 2008). The tick vectors are Ambylomma variegatum, A. cohaerens, A. haebraeum, Haemaphysalis bispinosa that these vectors are the probable vectors in Australia (Taylor et al., 2007).

Theileria velifera has been described in cattle and zebu and is very mild theileriosis in Africa (Taylor et al., 2007; Radostits et al., 2008 ). The tick vectors are Ambylomma variegatum, A. lepidu and A. haebraeum (Taylor et al., 2007).

Theileia taurotragi has been described in cattle, antelope and eland. Geographical distribution of this disease is in Africa. The tick vectors are Rhipicephalus appendiculatus and Rhipicephalus pulchellus (Taylor et al., 2007).

Thieleria mutans has been seen in cattle and deer (Carlson, 2009a).

Theileria hicri is malignant theileriosis of small ruminants (Lawrence, 2004; ), and is enzootic in North Africa, Middle East, China and India. The tick vectors are Rhipicephalus bursa and Hyalomma anatolicum (Taylor et al., 2007). 
Theileria ovis is benign theileriosis in Africa (Radostits et al., 2008). But in China Theileria ovis is a serious disease (Miling et al., 2009). The incidence and mortality rates of Theileria ovis in adult sheep and goats were have found $17.12 \%$ and $65.78 \% ; 8.06 \%$ and $73.33 \%$ respectively in China (Shuzhen et al., 2002). In Turkey, prevalence of infection of T. ovis in sheep and goats were have been $64.19 \%$ and $12.36 \%$, respectively ( Sayın et al., 2009). The tick vectors of disease are Rhipicephalus bursa in the Mediterranean and Rhipicephalus evertsi in Africa(Taylor et al., 2007).

\subsection{Pathogenesis}

Pathogenesis of different form of theileriosis is based on the production of schizonts in lymphocytes and piroplasms in erythrocyte. T. parva, T. annulata and T. hicri produce highly schizonts and piroplasma and are very pathogenic; T. mutans, T. buffeli, and T. ovis unusually produce schizonts but may cause varying degree of anemia when piroplasms are highly in red blood cells (Radostits et al., 2008).

\subsection{Clinical findings}

Theileia spp. are classified in to 2 groups. In first group (T. parva and T. annulata), proliferate is seen in lymphocytes but in the second group (T. orientalis) it is seen in erythrocytes that causes hemolytic anemia (Magona et al., 2010).

In Theileria parva incubation period is approximately1-3 weeks (Radostits et al., 2008). One or two days later, the first clinical sign is generalised swelling of the superficial lymph nodes, eyes, ears and submandibular regions. After few days there is anorexia, decreased milk production, loses condition, ceases rumination, rapid hearth beat, petechial haemorrhages under the tongue and on the vulva (Taylor et al., 2007). In cerebral theileriosis there are localized nervous signs and convulsions, tremor, salivation and head pressing (Radostits et al., 2008).

In Theileria annulata, pyrexia, anorexia, enlargement of superficial lymph nodes, nasal and ocular discharges and salivation is the most common signs. Constipation is recorded in some cases. Respiratory distress, coughing and pulmonary oedema are seen ( Osman and Gaabary, 2007).

In Theileria orientalis clinical signs are associated with anemia, jaundice and lymphadenopathy (Taylor et al., 2007).

Clinical signs in Theileria velifera is not reported but in Theileria taurotragi mild fever and anemia are reported (Taylor et al., 2007).

In Theileria hicri which is very pathogenic in sheep and goats, in the acute form there is fever, inappetence, ceases rumination, weakness, enlargement of superficial lymph nodes, diarrhoea, jaundice, haemorrhage in submucous may ocur. In chronic form there is fever, inappetence, emaciation, anemia and jaundice (Taylor et al., 2007). Theileria hicri is not reported in Turkey (Sayın et al., 2009).

Theileria ovis that is benign theileriosis in sheep and goats, clinically is mild (Taylor et al., 2007). 


\subsection{Diagnosis}

Investigation of giemsa-stained blood smears and lymph node biopsy will reveal piroplasms in erythrocytes and schizonts in lymphocytes. For diagnosis, indirect fluorescent antibody test (IFAT) and indirect enzyme-linked immunosorbent assay (ELISA) are the most commonly used techniques. The ELISA tests is more sensitive than IFAT (Taylor et al., 2007; Radostits et al., 2008).

\subsection{Treatment and control}

Buparvaquone is the most effective drug and the recommended dose in cattle, sheep and goat is 2.5mg / kg BW (Taylor et al., 2007; Radostits et al., 2008).

In control of the disease use of genetically resistant breed, a judicious and selective application of acaricides at 3- week intervals and the use of vaccines are recommended (Radostits et al., 2008).

\section{Sarcocystosis}

\subsection{Etiology}

Sarcocystosis caused by Sarcocystis species in cattle, sheep and goats. The names of Sarcocystis species are according to their intermediate and final hosts (Taylor et al., 2007; Radostits et al., 2008). The list of sarcocystis species is shown in table 3.

\begin{tabular}{|l|l|l|l|l|}
\hline Species & Synonyms & $\begin{array}{l}\text { Intermediate } \\
\text { host }\end{array}$ & Definitive host & $\begin{array}{l}\text { Geographic } \\
\text { distribution }\end{array}$ \\
\hline S. bovicanis & S. cruzi & Cattle & Dog, wolf & Worlwide \\
\hline S. bovifelis & S. hirsuta & Cattle & Cat & Worlwide \\
\hline S. bovihominis & S. hominis & Cattle & Human & Worlwide \\
\hline S. ovicanis & S. tenella & Sheep & Dog, fox & Worlwide \\
\hline S. ovifelis & S. gigantica & Sheep & Cat & Worlwide \\
\hline S. capracanis & - & Goats & Dog, wolf & Worlwide \\
\hline S. hircicanis & - & Goats & Dog & Worlwide \\
\hline S. hircifelis & S. moulei & Goats & cat & Worlwide \\
\hline
\end{tabular}

Table 3. Sarcocystis species (Sarcocystosis)

\subsection{Epidemiology}

Sarcocystosis occur in all of countries (Taylor et al., 2007; Radostits et al., 2008).

\subsection{Pathogenesis}

Sarcocystis spp, are protozoon parasites with a requisite two-host life cycle. Sexual reproduction phase occur in the intestine of a carnivore (dogs, cats) later, cysts in the muscles of cattle, sheeo or goats. Sporocysts are shedded by carnivore's feces and then ingested by cattle, sheep, or goats. Then sporocysts hatch in the ruminant small bowel and invade the vascular endothelium during three phases of asexual reproduction. After third phase, merozoites enter the ruminant's muscle tissue and encyst as sarcocysts (Smith and George, 2009; Reilly et al., 2002). 


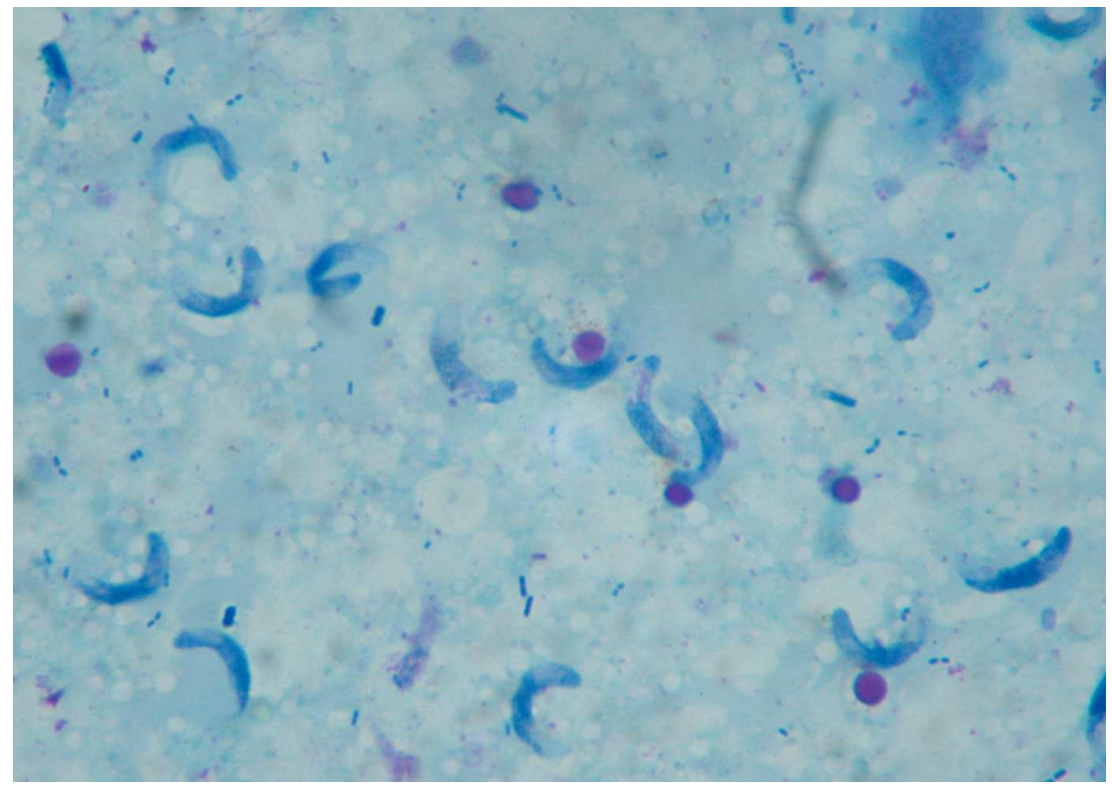

Fig. 4. Sarcocystis spp. bradizoit smear, impression smear, Giemsa staining, immersion objective

\subsection{Clinical findings}

In cattle is usually asymptomatic, but in heavy infections and nonimmune cattle, clinical signs include fever, anorexia, anemia, weight loss, lameness, abortion and diarrhea (Taylor et al., 2007; Radostits et al., 2008). Neurologic signs are occasionally seen in cattle that include ataxia, tremors, muscular weakness, hypersalivation, blindness, opisthotonos and nystagmus (Radostits et al., 2008; Smith and George, 2009 ). In infections that caused by Sarcocystis bovicanis in cattle there is usually loss of hair at the end of the tail (Taylor et al., 2007).

In sheep and goats clinical signs may be asymptomatic. In heavy infections there is fever, loss of weight, anemia and weakness. Abortion may occur (Taylor et al., 2007).

In chronic infections clinical signs include poor weight gain, edema of the limbs, anemia and abortion (Smith and George, 2009). Neurological disorder that is described in sheep caused by S. Tenella and S. Arieticanis (Radostits et al., 2008). Neurological symptoms, such as depression, in coordination, hind leg paralysis and coma can be seen in Encephalitic Sarcocystosis (Ozmen et al., 2009).

\subsection{Diagnosis}

Generally Sarcocystis infections are diagnosed at meat inspection with grossly visible sarcocysts in the animala's muscle. When infection is very heavy in intermediate hosts, clinical signs and histological evidence of schizonts in the blood vessels of organs and the presence of cysts in the muscles at necropsy will be used for diagnosis (Urquhart et al., 1987). 
Indirect hemagglutination test (IHA) and ELISA test are used for serological diagnosis. In acute form of disease titers of antibodies are not high but 1week to 3 months later will be at diagnostic levels. For certain diagnosis immunohistochemistry, electron microscopy and PCR techniques are available (Radostits et al., 2008).

\subsection{Treatment and control}

There is no effective treatment for sarcocystosis described in the literature (Urquhart et al., 1987; Radostits et al., 2008; Smith and George, 2009). Treatment of infected calves and sheep with salinomycin (4 mg / $\mathrm{kg}$ and 1-2 $\mathrm{mg} / \mathrm{kg}$ BW; respectively) has been recommended. Amprolium $100 \mathrm{mg} / \mathrm{kg}$, for 30 days reduces the severity of infection (Radostits et al., 2008; Smith and George, 2009).

After beginning nervous system symptoms in sheep, Encephalitic Sarcocystosis recovery has not been observed (Ozmen et al., 2009).

Control of disease is based on protection the food supply of ruminants. Feed bunk should be kept clean, also farm dogs and cats that have access to the feed or pastures should not be fed uncooked meat (Urquhart et al., 1987; Smith and George, 2009).

\section{Neosporosis}

\subsection{Etiology}

Neosporosis caused by Neospora caninum in cattle, sheep and goats. Neospora caninum is a protozoan parasite of the phylum Apicomplexa in the family Sarcocystidae (Radostits et al., 2008; Matthewa, 2009).

The list of sarcocystis specie is shown in table 4.

\begin{tabular}{|l|l|l|l|}
\hline Specie & Intermediate host & Definitive host & Geographic distribution \\
\hline N. caninum & Cattle, sheep, goats & Dog & Worlwide \\
\hline
\end{tabular}

Table 4. Neosporosis

\subsection{Epidemiology}

The protozoa Neospora caninum is an important parasite that cause abortion in cattle, sheep and goats (Gumber et al., 2002). The majority of N. caninun- positive cattle prenatally infected via their dams. Transplacental transmission is considered the major route of transmission of N. caninum in cattle (Schares and Conraths, 2007).

In nonfatal infection in the fetus, the fetus is born with neurologic disorder (Smith and George, 2009).

$\mathrm{N}$. caninum has a worldwide distribution, the prevalence of infection in cattle and sheep approaches $100 \%$ with a lower ((Taylor et al., 2007; Radostits et al., 2008).

\subsection{Pathogenesis}

Definitive host: Dogs are the final host and sexual phase occur in them but, they are also intermediate host in prenatal infections (Taylor et al., 2007; Matthews, 2009). 
Intremediate host: Cattle are the major intermediate hosts and asexual reproduction phase ocur in them (Matthews, 2009 ). Infection can be transmitted from dam to calf in utero and lactogenically. Infection of cattle can also occur from the ingestion of food or water contaminated with dog feces containing Neospora caninum oocysts (Taylor et al., 2007; Radostits et al., 2008). Neospora caninum is a major cause of abortion in cattle, however, sporadic abortions can occur in beef cows that have been infected congenitally (Dubey et al., 2006; Taylor et al., 2007; Radostits et al., 2008; Matthewa, 2009 ).

Asexual phase has 2 stages:

1. Tachyzoites: Tachyzoites penetrate host cell like central nervous system, muscles, macrophages and other cells, where they divide rapidly. Tachyzoites can also be transmitted either with contaminated food and water or transplacentally to the fetus in pregnant animals. Tissue cyst containing bradyzoites that these are found only in the nervous system. After the asexual phase, sexual phase ocur in definite host. It results in production of oocysts, which is shed in the dog feces.

2. Tissue cysts (Taylor et al., 2007).

Infection in sheep and goats is infrequently (Radostits et al., 2008).

\subsection{Clinical findings}

In cattle, Neosporosis causes stillbirth, fetal resorption, mummification, abortion and decreases in their milk production(Gumber et al., 2002; Radostits et al., 2008). Abortions in cows are seen between 5-7 month gestations (Gumber et al., 2002). Fetus may born alive but congenitally diseased (Gumber et al., 2002; Radostits et al., 2008).

Neurological symptoms are different because of the widespread distribution of the parasite in the central nervous system. Calves are born with neurological symptoms, which these symptoms initially are mild but after birth become progress. In calves with neurologic dysfunction clinical signs are included of unable to stand, unable to suckle, domed skull and torticollis (Smith and George, 2009).

\subsection{Diagnosis}

The diagnosis of neosporosis is based on the examination of maternal and fetal sera ideally combined with the examination of fetal tissues.

- Immunofluorescent antibody test (IFAT) and indirect enzyme-linked immunosorbent assay (ELISA) are used for diagnosis.

- Histopathology of fetus: In histopathological examination of brain characteristic nonsuppurative encephalitis is suggestive of Neospora infection and also the lesions in the heart are characteristic for diagnosis (Gumber et al., 2002; Taylor et al., 2007; Matthews, 2009).

\subsection{Treatment and control}

At present, there is no effective treatment for bovine neosporosis.

Control of abortion in infected cattle depends on saving food and water sources and the grazing environment from feces of any animal. Aborted fetuses and placentas should be removed or incinerated. The feces of dogs should be prevented from contaminating animal foodstuffs. 
Congenitally infected cows are at high risk for abortion thus seropositive animals should be culling from a herd (Taylor et al., 2007; Radostits et al., 2008).

\section{Coccidiosis}

\subsection{Etiology}

Coccidiosis is a protozoan parasitic (genus Eimeria) disease that cause diarrhea in calves, lambs and kids (Radostits et al., 2008).

There are 12 species of Eimeria in cattle but all of them may not be pathogenic ( Table 5).

The species that identified in sheep and goats is shown in table 6 and table 7 .

\begin{tabular}{|l|l|l|}
\hline Specie & Affinity site & Hosts \\
\hline E. zuernii & Small and large intestine & Cattle, zebu, water buffalo \\
\hline E. bovis & Small and large intestine & Cattle, zebu, water buffalo \\
\hline E. auburnensis & Small intestin & Domestic cattle, zebu, buffalo \\
\hline E. alabamensis & Small and large intestine & Domestic cattle, zebu \\
\hline E. bukidnonensis & unknown & Domestic cattle, zebu, buffalo \\
\hline E. cylindrica & unknown & Domestic cattle, zebu, buffalo \\
\hline E. canadensis & unknown & Domestic cattle, zebu \\
\hline E. ellipsoidalis & Small intestine & Domestic cattle, zebu \\
\hline E. pellita & unknown & Bovine \\
\hline E. subspherica & unknown & Domestic cattle, zebu, water buffalo \\
\hline E. wyomingensis & unknown & Cattle, zebu, water buffalo \\
\hline E. brasiliensis & unknown & Cattle, zebu, water buffalo \\
\hline
\end{tabular}

Table 5. Eimeris species identified in cattle.

\begin{tabular}{|l|l|l|}
\hline Specie & Affinity site & Hosts \\
\hline E. crandallis & Small and large intestine & $\begin{array}{l}\text { Rocky Mountain big-horn sheep, domestic } \\
\text { sheep, moufflon }\end{array}$ \\
\hline E. ahsata & Small intestine & $\begin{array}{l}\text { Domestic sheep, Rocky Mountain big-horn } \\
\text { sheep, moufflon }\end{array}$ \\
\hline E. faurei & Small and large intestine & Sheep, Rocky Mountain big-horn sheep \\
\hline E. intricata & Small and large intestine & $\begin{array}{l}\text { Domestic sheep, Rocky Mountain big-horn } \\
\text { sheep }\end{array}$ \\
\hline E. ovinoidalis & Small and large intestine & Domestic sheep, big-horn sheep, moufflon \\
\hline E. pallida & unknown & Domestic sheep \\
\hline E. parva & Small and large intestine & $\begin{array}{l}\text { Domestic sheep, Rocky Mountain big-horn } \\
\text { sheep, Barbary sheep }\end{array}$ \\
\hline E. granulosa & unknown & $\begin{array}{l}\text { Domestic sheep, Rocky Mountain big-horn } \\
\text { sheep }\end{array}$ \\
\hline E. marsica & unknown & Domestic sheep \\
\hline E. bakuensis & Small intestine & Domestic sheep \\
\hline E. weybridgensis & Small intestine & Domestic sheep \\
\hline
\end{tabular}

Table 6. Eimeris species identified in sheep. 


\begin{tabular}{|l|l|l|}
\hline Specie & Affinity site & Hosts \\
\hline E. alijevi & Small and large intestine & Domestic goat \\
\hline E. caprina & Small and large intestine & Domestic goat \\
\hline E. ninakohlyakimovae & Small and large intestine & Domestic goat, Ibex, persian gazelle \\
\hline E. arloingi & Small intestine & Domestic goat, Ibex, angora \\
\hline E. christenseni & Small intestine & Domestic goat \\
\hline E. aspheronica & unknown & Domestic goat \\
\hline E. caprovina & unknown & Domestic goat \\
\hline E. hirci & unknown & Domestic goat \\
\hline E. jolchijevi & unknown & Domestic goat \\
\hline
\end{tabular}

Table 7. Eimeris species identified in goats.

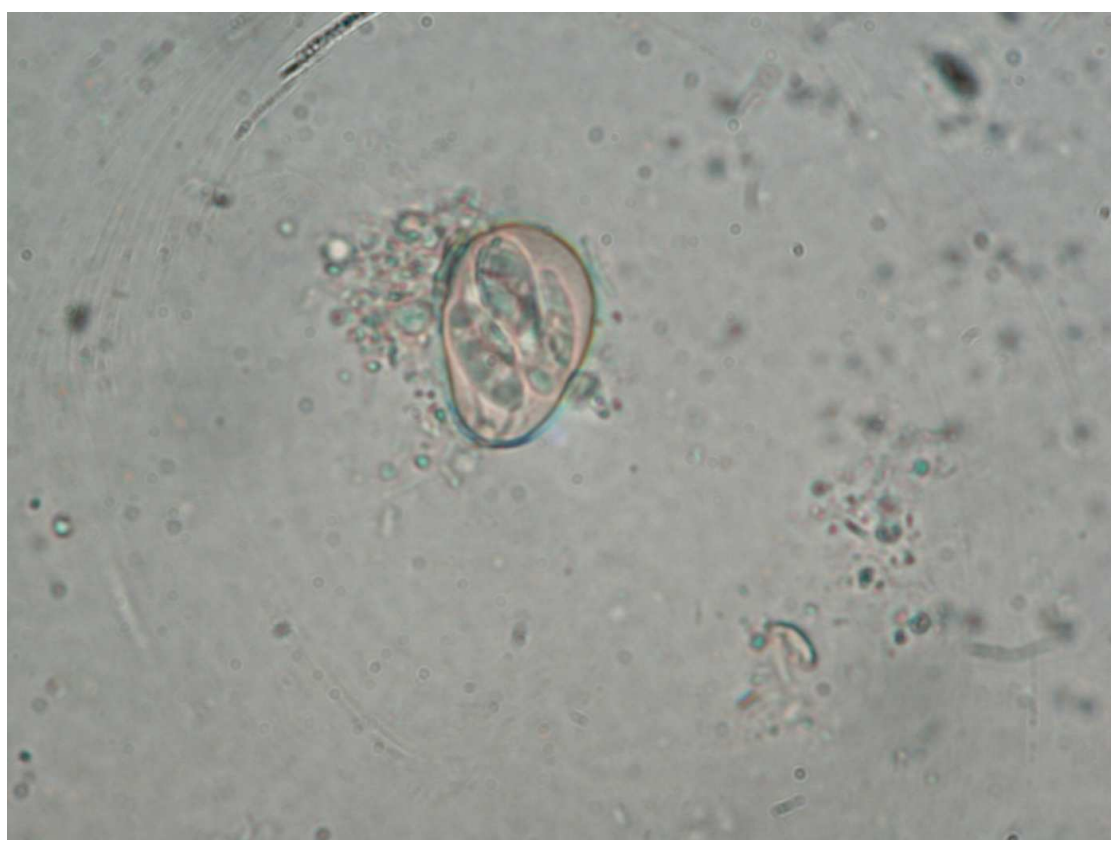

Fig. 5. Eimeria spp. sporulated oocyst, calve, 40X 


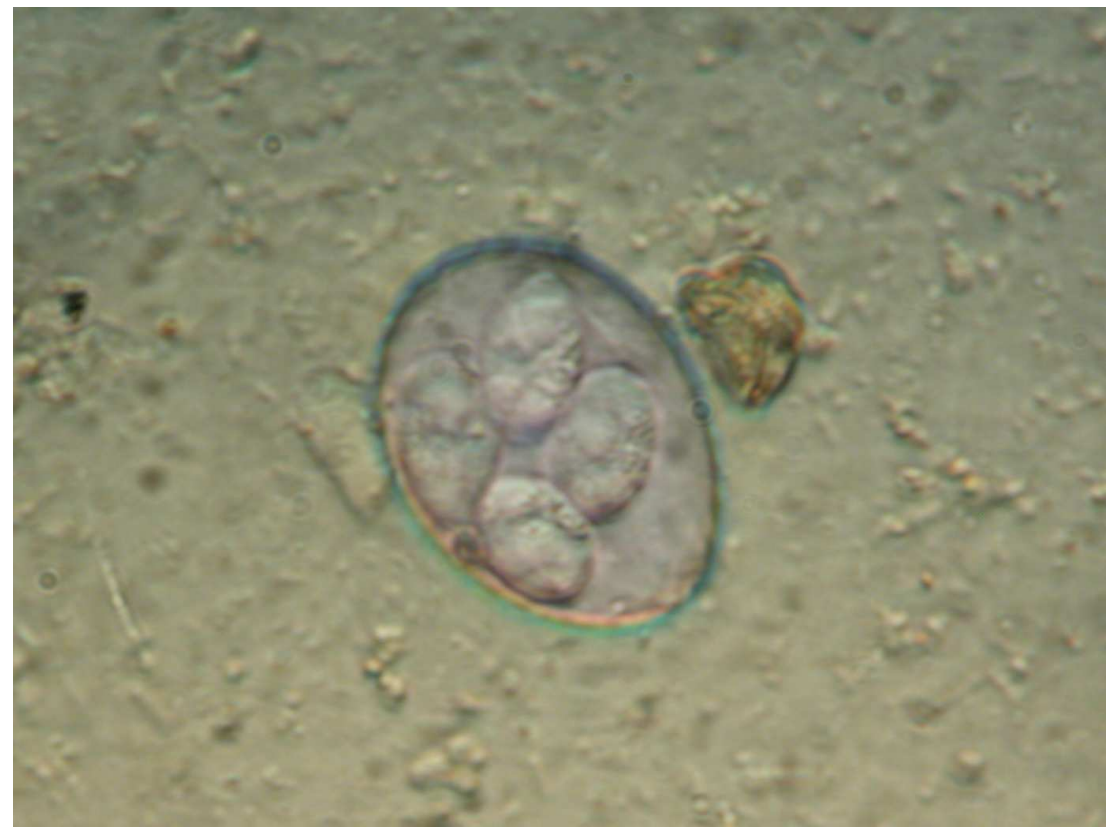

Fig. 6. Eimeria spp. sporulated oocyst, lamb, 40X

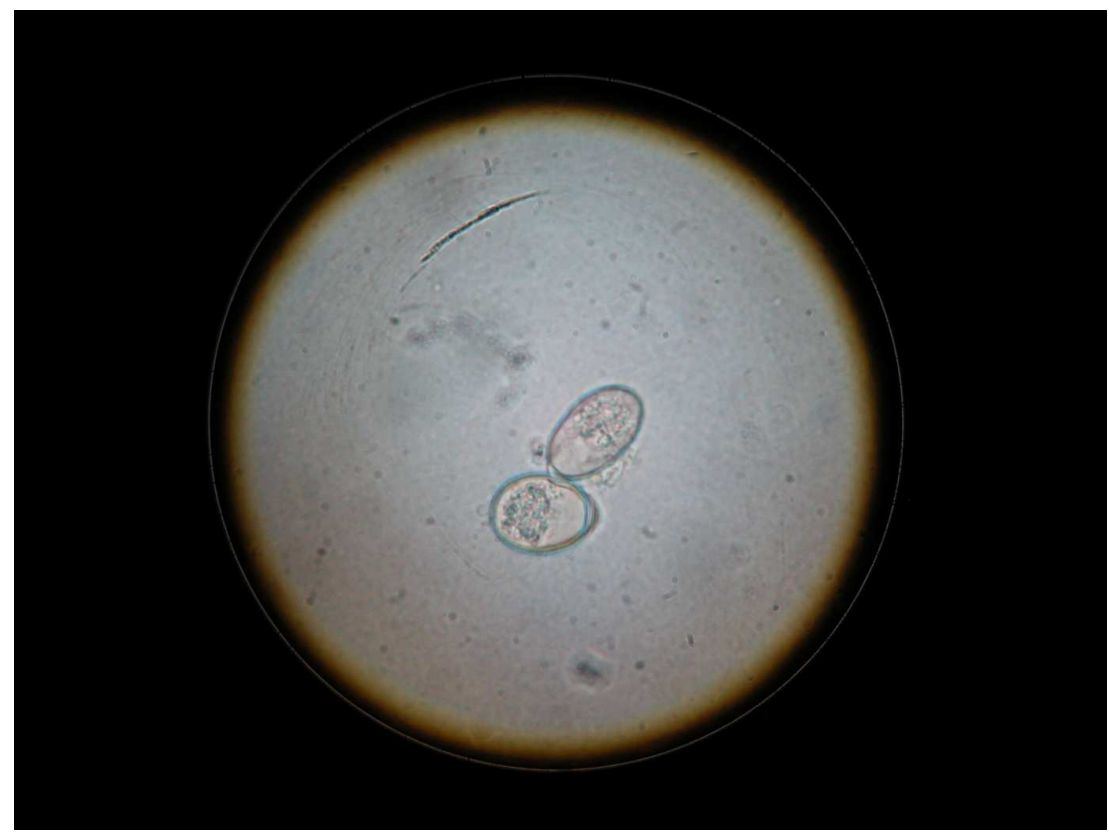

Fig. 7. Eimeria spp. sporulated oocyst, kid, 40X 


\subsection{Epidemiology}

\subsubsection{Bovine coccidiosis}

Coccidiosis occurs universally in young animals normally in calves between 3 weeks and 6 months of age and caused important economic losses but also has been reported in cattle aged 1 year or more (Radostits et al., 2008; Ballweber, 2009). The disease occur in animals that kept in crowded and contaminated pens. The prevalence in calves is $46 \%$, in yearling is $43 \%$ and in adult cows is 16\% (Radostits et al., 2008). Eimeria zuernii is the most pathogenic species that causing haemorrhagic diarrhoea (Taylor et al., 2007).

In Turkey the most prevalent species are E. bovis (17.6-58.5\%), E. zuernii (12.7-47.3\%). E. auburnensis (4.5-64.7\%) and E. canadensis (4.1-64.7\%) (Ozer and Saki, 2001). The prevalence of infection in calves $60-90 \%$ have been reported in Tuekey (Arslan and Sari, 2010).

\subsubsection{Sheep and goats coccidiosis}

Coccidiosis in sheep and goats is caused by protozoa of the genus Eimeria. Coccidiosis is one of the most common, important and higher infection rates disease in lambs and kids that kept in small areas contaminated with oocysts (Radostits et al., 2008).

In Turkey, the identified species in sheep are E. ahsata, E. bakuensis, E. crandallis, E. granulosa, E. intricata, E. marsica, E. ovinoidalis, E. pallida, E. parva, E. punctata and E. weybridgensis and in goats are E. arloingi, E. christenseni, E. alijevi, E. hicri, E. caprina, E. caprovina, E. jolchijevi, E. apsheronica, E. crandallis, E. fauri, E. granulosa, E. ninakohlyakimovae, E. pallida, E. parva and E. punctata (Arslan and Sari, 2010).

\subsection{Pathogenesis}

The pathogenesis of the disease is dependent on the destroy of the crypt cells of the intestinal mucosa because in the ruminant small intestine is very long and providing a high number of host cells and is a potential for parasite replication with minimal damage. Some E. species that invade the large intestin, cause pathological changes, specially when large numbers of oocysts are ingested in a short period of time (Taylor et al., 2007).

In healthy nonimmune animals when number oocysts ingested is low, the animals show no clinical signs of disease but in many oocysts condition, rupture and exfoliation of intestinal cells triggers intestin function and causes loss of blood, fluid, albumin and electrolytes into the intestin. Disaster of mucosal capillaries of intestin can cause to hypoproteinemia and anemia. Secondary bacterial infection may cause severe enteritis(Ballweber, 2009)

\subsection{Clinical findings}

In most clinical cases the temperature is normal or subnormal. Disaster of epithelial cells of intestine cause sometimes bloody diarrhea. Dehydration may occur but anemia occasionally may be seen. In severe infections, diarrhea which may be mucoid or bloody, tenesmus, abdominal pain, anorexia, dehydration and weight loss are the common clinical signs in coccidiosis (Radostits et al., 2008; Ballweber, 2009).

In the calves that infected with high number of oocysts may developed dysentery. Clinical coccidiosis occurs rarely in adult cattle (Radostits et al., 2008). 
Coccidiosis in lambs is widely similar to that in calves, but dysentery do not usually ocur. In infected kids clinical signs are associated with watery diarrhea, dehydration, anorexia, and weight loss (Ballweber, 2009).

\subsection{Diagnosis}

Diagnosis is based on history, clinical and necropsy findings, and microscopic examination of feces. Acute coccidiosis can be diagnosed by direct examination of feces but in chronic coccidiosis that very low oocysts number are seen in feces, direct examination of feces may not be adequate (Navarre and Pugh, 2002).

\subsection{Treatment and control}

Coccidiostats drugs are used for treatment. All animals in the flock should be treated. Trimetoprim+Sulfadoxine $(16-24 \mathrm{mg} / \mathrm{kg})$ can be used for three days by intramuscularly in lambs and kids (Ozmen et al., 2004). Amprolium (10 mg/kg BW) for 5 days or $65 \mathrm{mg} / \mathrm{kg}$ BW one dose can be effective in calves (Radostits et al., 2008). Diclazuril and toltrazuril are also coccidiocidal drugs (Matthews, 2009). Ghanem et al., (2008), suggested that toltrazuril is more effective than sulphadimine and amprolium in E. Bbovis and E. zuernii oocysts shedding in buffalo calves.

Because of the low serum vitamin $C$ levels in lambs with coccidiosis, administration of vitamin $C$ is suggested to be useful combined with the classical treatment (Sahinduran et al., 2006).

Hygiene in the house, minimisation of predisposing factors, avoiding the overcrowding of animals in the pens, control of the pastures for parasite are important factors for the control of coccidiosis.

\section{Cryptosporidiosis}

\subsection{Etiology}

Cryptosporidium are protozoan parasite with at least 13 species occuring in mammals, birds, and fish, but only 2 of these species are important in livestock animals (Taylor et al., 2007; Radostits et al., 2008). Cryptosporidium spp. are intracelluler protozoan parasites causing gastrointestinal disease and diarrhea, and they are important infection in young ruminants.

The list of cryptosporium specie is shown in table 8.

\begin{tabular}{|l|l|l|}
\hline Specie & Affinity site & Hosts \\
\hline Cryptosporidium parvum & Small intestine & Cattle, sheep, goats, deer, man \\
\hline Cryptosporidium andersoni & Abomasum & Cattle \\
\hline
\end{tabular}

Table 8. Cryptosporidia species 


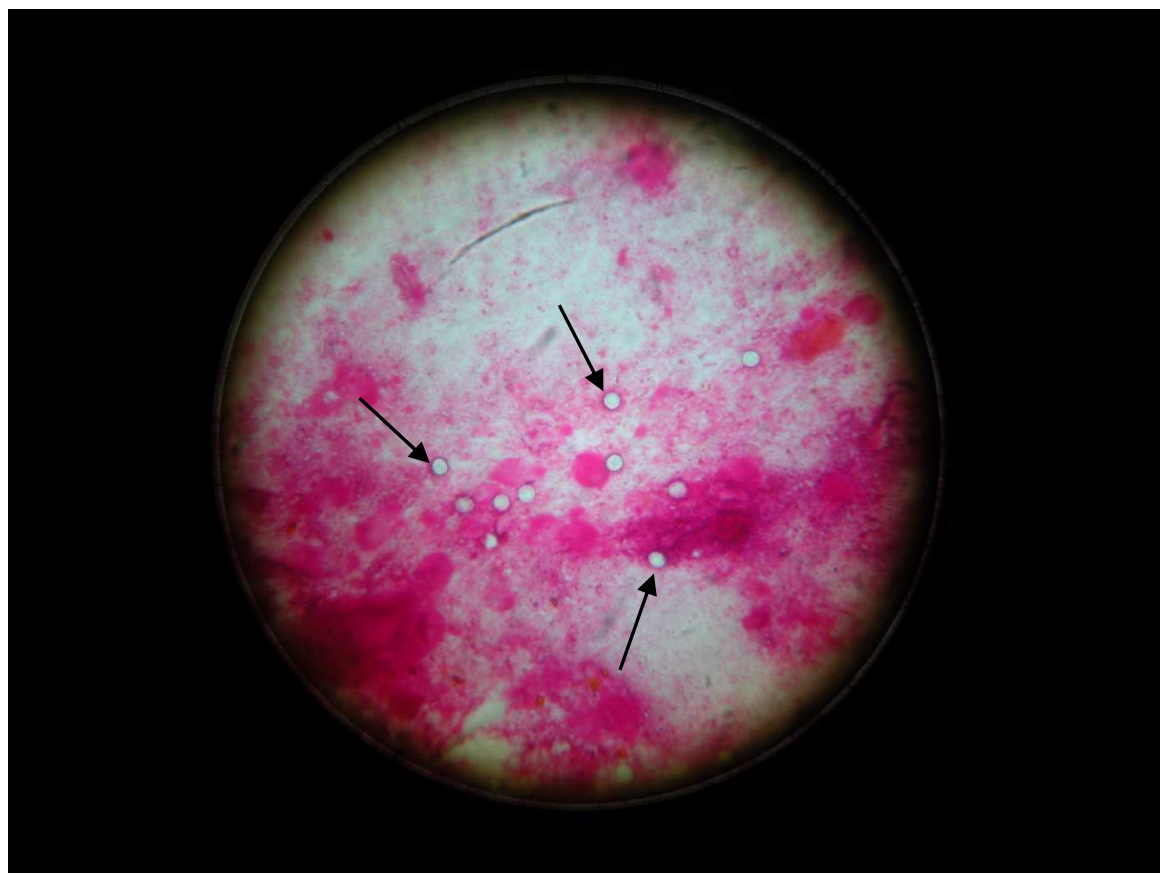

Fig. 8. Cryptosporidium spp. oocyst, calve, carbol- fuchsin staining, 40X

\subsection{Epidemiology}

Cryptosporidiosis occur primarily in neonatal calves, but also in lambs and kids (Radostits et al., 2008). One major species, C. Parvum, infects both farm animals and humans (Jones et al., 1997). Cryptosporidiosis is a fairly prevalent disease in many countries, and the disease is one of the most economically important diseases especially in calves and kids in Turkey (Sevinc, 2004). Calves at 1-15 days are at the highest risk (El- Khodery and Osman, 2008). The higher percentage of oocysts excreted is observed in 7-day-old calves (Feitosa et al., 2008). Animals of all ages can be infected, but diarrhea occur only in young animals (Gunn et al., 2009). In young calves there is a significant relationship between season and infection (El- Khodery and Osman, 2008). Infection peaks occur in spring and autumn (Taylor et al., 2007). Castro-Hermida et al.,(2007), suggested that asymptomatic adult sheep and goats are the source of environmental contamination by C. Parvum.

\subsection{Pathogenesis}

Cryptosporidium parvum infection, cause a malabsorptive diarrhea (Navarre and Pugh, 2002). Cryptosporium life cycle consist of six developmental stages. After ingestion of the oocyt there is excystation, merogony, gametogony, fertilization, oocyst wall formation, and sporogony.In contrast to other protozoal agents, cryptosporidia do not require fecal excretion for sporulation to infective stages, and they sporulate in the intestine (Navarre and Pugh, 2002; Radostits et al., 2008). 


\subsection{Clinical findings}

Infections that caused by Cryptosporidium andersoni, are usually asymptomatic, although depressed weight gain in calves and milk yields in milking cows have been reported (Taylor et al., 2007).

In Cryptosporidium parvum infections, clinical signs are characterised by anorexia, depression, weight loss, diarrhea, dehydration, high morbidity and possibly death because of dehydration. Cryptosporidium parvum can cause diarrhea in calves 5to15, and in lambs and kids 5to10 days of age (Navarre and Pugh, 2002; Radostits et al., 2008). Relapses of diarrhea are quite common, and Cryptosporidium parvum usually occurs as a component of mixed infections (Navarre and Pugh, 2002).

\subsection{Diagnosis}

Oocysts can be detected using Ziehl-Nielsen stained fecal smears Cryptosporidia can be diagnosed by fecal flotation. A number of molecular and immunological assays are available for diagnosis for example immunofluorescence (IF) or enzyme-linked immunosorbent assays (ELISA) (Taylor et al., 2007).

Cryptosporidiosis is a zoonotic disease, and human can become infected from handling infected animals or feces.

\subsection{Treatment and control}

There is no effective drug for treatment of cryptosporidiosis in ruminants (Navarre and Pugh, 2002).

Halofuginone has efficacy in calves with diarrhea due to Cryptosporidium parvum. Halofuginone is reported to reduce oocyst shedding and the intensity of diarrhea. Oral dose of $0.1 \mathrm{mg} / \mathrm{kg}$ BW daily for 7 days can reduce oocyte excretion (Klein, 2008).

Decoquinate, $2.5 \mathrm{mg} / \mathrm{kg}$, can be effective in prevention of cryptosporidiosis in kids and goats (Navarre and Pugh, 2002; Matthews, 2009).

Cryptosporidiosis in young animals should be treated with fluid therapy and correction of acid-base disturbance.

The control of disease is based on the minimize transmission between the source of the organism and young animals. During the course of the diarrhea, diarrheic young animals should be isolated from healthy animals (Radostits et al., 2008). The best control of cryptosporidiosis comes from calves, lambs, and kids getting adequate immunity through colostrum after birth.

\section{Giardiasis}

\subsection{Etiology}

Giardiasis is the infection caused by the flagellate intestinal protozoan, Giardia intestinalis, which is also known as G. duodenalis, or G. lamblia. Infection occur in a wide range of domestic and wild animals and also humans. G. intestinalis is a potential pathogen in 
livestock, causing diarrhea, weight loss, poor condition and lethargy (Hunter and Thompson, 2005). The parasite is a noninvasive and colonizes the mucosal surface of the small intestine.

The Giardia specie is shown in table 9.

\begin{tabular}{|l|l|l|l|}
\hline Specie & Affinity site & Hosts & $\begin{array}{l}\text { Geographic } \\
\text { distribution }\end{array}$ \\
\hline Giardia intestinalis & Small intestine & Cattle, sheep, goats, man & Worlwide \\
\hline
\end{tabular}

Table 9. Giardiasis

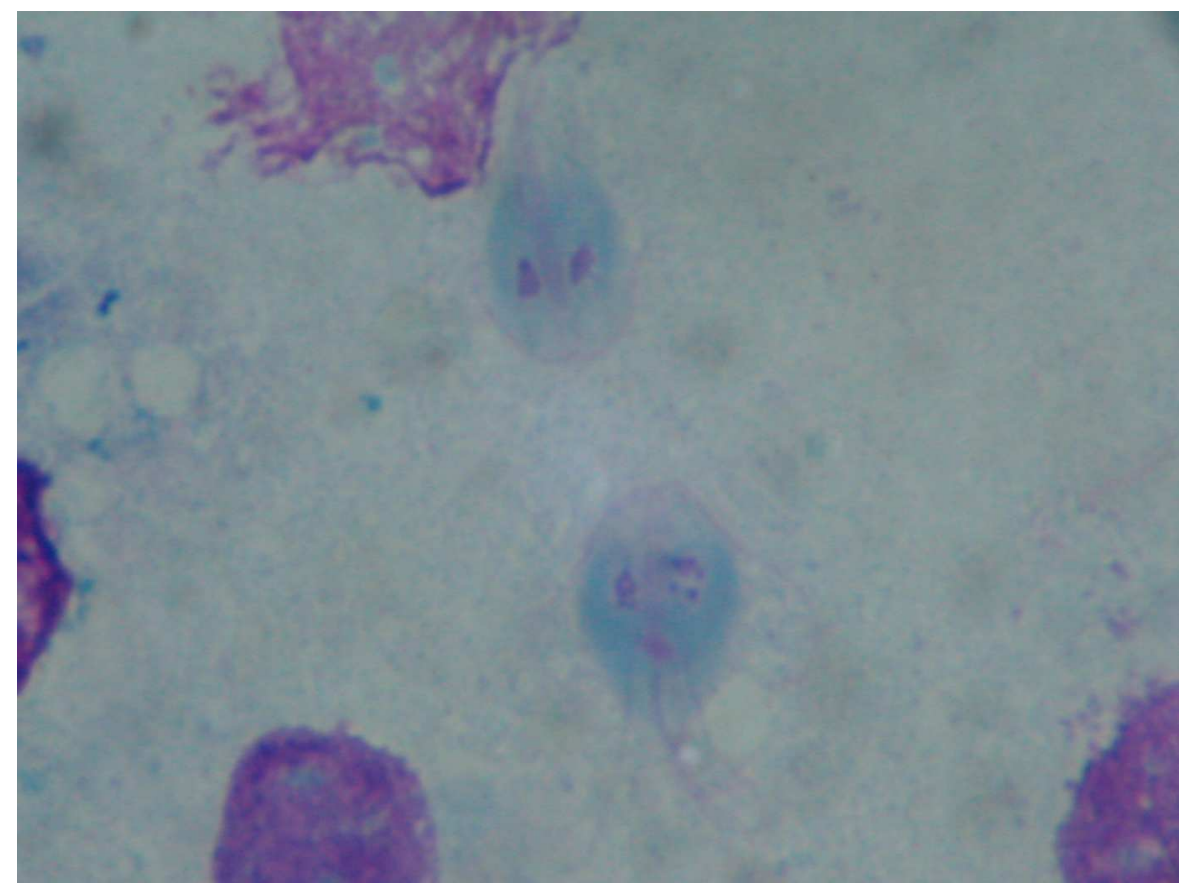

Fig. 9. Giardia spp. trophozoit, lamb, Giemsa staining, immersion objective

\subsection{Epidemiology}

Giardia intestinalis is an important parasite in domestic ruminants also, in human with high levels of infection. Asymptomatic adult animals may act as healthy transporters and may be a source of environmental contamination and infection for young animals. Infection is commonly exhibited by the animals within 2 weaks of birth (Xiao, 1994). Diarrhea may be transient, but infected animals can continue to shed cysts for long times.

Olson et al., (2004) reported a high levels of infection of Giardia in young livestock, specially calves. Giardia occur in both beef and dairy cattle, and studies have demonstrated prevalence rates of $100 \%$ (Xiao and Herd, 1994). 


\subsection{Pathogenesis}

The pathogenesis of giardiasis is similar to cryptosporidiosis. The parasite cause diffuse injure to the small intestinal mucosal surface. Giardia infection cause a reduction in the height of the villus and microvillus, and loss of the absorptive surface area throughout the small intestine. If disease occur in animals, it is believed to result from nutrient malabsorption and due to diarrhea.

\subsection{Clinical findings}

Clinical signs of giardiasis include acute or chronic diarrhea, dehydration, weight loss, abdominal pain and reduction in weight gain. The diarrhea may be continuous or intermittent.

\subsection{Diagnosis}

Diagnostic methods for introduce of giardia include direct microscopy, fluorescent antibody staining, ELISA, and PCR(Gunn et al., 2009).

\subsection{Treatment and control}

Infected sheep and goats can be treated with fenbendazole $(5-10 \mathrm{mg} / \mathrm{kg}$ ) for 3 days (Navarre and Pugh, 2002). Fenbendazole (10 mg / kg BW daily for 3 days) and albendazole ( $20 \mathrm{mg} / \mathrm{kg}$ BW daily for 3 days), have been shown also to be effective in calves (Thompson, 2004; Radostits et al., 2008). Geurden et al., (2006), demonstrated the efficacy and safety of a 5 day treatment with paromomycin against an experimental Giardia infection in calves. Ozmen et al., (2006), suggested that five day treatment with Trimethoprim + Sulfodoxine and multivitamin complexes can be effective in the prevention and treatment of Giardia intestinalis in lambs and kids.

Re-infection frequently occurs if the sources of contamination are not eliminated and the frequency of transmission is high (Thompson, 2004).

\section{Besnoitiosis}

\subsection{Etiology}

Besnoitia are protozoan parasite with classified 7 species, which only 2 of these species are important in livestock animals. Besnoitiosis is a emergent parasitic disease that caused by Besnoitia besnoiti in cattle, and Besnoitia caprae in goats. These parasites are in the family Sarcocystidae (Radostits et al., 2008), and they are an obligate intracellular apicomplexan protozoan parasites (Majzoub et al., 2010).

The Besnoitia species are shown in table 10.

\begin{tabular}{|l|l|l|l|}
\hline Specie & Affinity site & Intermediate hosts & Definitive host \\
\hline Besnoitia besnoiti & Skin, conjunctiva & Cattle & Cat, wild cats (Lion, leopard) \\
\hline Besnoitia caprae & Skin, conjunctiva & Goats & Cat, wild cats (Lion, leopard) \\
\hline
\end{tabular}

Table 10. Besnoitia species 


\subsection{Epidemiology}

Disease occur as outbreaks in tropical and subtropical countries and sporadically in other countries (Radostits et al., 2008). Bovine besnoitiosis is common in Africa, Asia and in the South of Euroup ( Jacquiet et al., 2010), Caprine besnoitiosis in Kenya, Uganda, Iran, and Kazakhastan. In livestock, cattle and goats are intermediate host, and cats are their definitive hosts (Radostits et al., 2008). It is thought that agent is transmitted mainly by hematophagous insects (Jacquiet et al., 2010).

\subsection{Pathogenesis}

Following infection in cattle or in goats, the tachyzoites proliferate in macrophages, fibroblasts, and endothelial cells and causing vasculitis. Subsequently they develop to form bradyzoite cysts in fibroblasts in the dermis, subcutaneous tissues, fascia, nasal and laryngeal mucosa (Taylor et al., 2007; Radostits et al., 2008). After developing cysts in the skin, painful subcutaneous swelling, thickening of the skin, alopecia, and necrosis can be occur (Taylor et al., 2007).

\subsection{Clinical findings}

\subsubsection{Bovine besnoitiosis}

Clinical signs occur in two stages: acute and chronic. In acute stage clinical signs include fever, increase in pulse and respiratory rates, painful swelling on the ventral aspects of the body, edema of the skin, sometimes diarrhea, lacrimation and nasal discharge. In chronic stage, there is a severe dermatitis over most of the body (Radostits et al., 2008).

\subsubsection{Caprin besnoitiosis}

Thickening of the skin over the lower limbs, around the eyes, nose, face and scrotum, alopecia in all of these areas, and white granular cysts in the sclero-conjunctiva can be seen (Oryan and Azizi, 2008).

\subsection{Diagnosis}

Besnoitiosis can be diagnosed by demonstration of B. bradyzoites in skin biopsy smears or scleral conjunctival scrapings (Radostits et al., 2008).

\subsection{Treatment and control}

There is no known treatment for this disease (Taylor et al., 2007).

Control is effected by the elimination of infected animals and carriers, and early diagnosis ( Antonio Castillo et al., 2009).

\section{Toxoplasmosis}

\subsection{Etiology}

Toxoplasma gondii is a systemic coccidian, a universal parasite that causes rarely abortion in cattle but is a major abortifacient in sheep and goats (Radostits et al., 2008; Christensen et 
al., 2009). Felids are the definitive hosts, and there are wide range of intermediate hosts in this disease (Radostits et al., 2008).

Toxoplasma specie is shown in table 11.

\begin{tabular}{|l|l|l|l|}
\hline Specie & Affinity site & Intermediate hosts & Definitive host \\
\hline Toxoplasma gondii & $\begin{array}{l}\text { Muscle, liver, } \\
\text { lung, reproductive } \\
\text { system, central } \\
\text { nervous system }\end{array}$ & $\begin{array}{l}\text { Cattl, sheep, goats, } \\
\text { man, and all warm } \\
\text { blooded animals }\end{array}$ & cats \\
\hline
\end{tabular}

Table 11. Toxoplasmosis

\subsection{Epidemiology}

Toxoplasmosis is one of the most common parasitic infections of man and other warmblooded animals in most parts of the world (Hill et al., 2002). The disease is a major cause of ovine abortion in many countries (Christensen et al., 2009). Seroprevalence studies show high rates of infection in farm animals. Major importance of disease in farm animals is its zoonotic potential. Source of infection for sheep, and cattle is the oocyst passed in the feces of the cats. Cats shed oocysts by their feces. Cats infected by ingesting tissues of intermediate hosts (Radostits et al., 2008).

\subsection{Pathogenesis}

The whole developmental process of Toxoplasma gondi requires two hosts, the definitive host, cat and the intermediate host (all warm blooded animals).

There are three stages of Toxoplasma gondii that are infectious for all hosts: tachyzoites, bradyzoites, and oocysts.

- Tachyzoites: This form of the parasite present during the acute stage of infection in the intermediate host.

- Bradyzoites: present in the tissue cysts. tissue cysts can develop in lungs, liver, and kidneys, and they are more prevalent in muscular and neural tissues, including the brain, eye, skeletal, and cardiac muscle.

- Oocysts: Present only in cat feces and containing sporozoites. Cats shed oocysts after ingesting tachyzoites, bradzyoites, or oocysts. Oocysts are the infective form of importance in livestock animals (Dubey et al., 1998; Radostits et al., 2008).

\subsection{Clinical findings}

There are a few reports of clinical toxoplasmosis in cattle associated with fever, dyspnea, nervous signs and abortion (Taylor et al., 2007).Toxoplasma is not significant in bovine abortion (Radostits et al., 2008). In small ruminants, particularly in sheep clinical signs include fever, abortion, prenatal mortality in lambs, generalized tremor, and dyspnea (Taylor et al., 2007; Radostits et al., 2008). 


\subsection{Diagnosis}

Diagnosis is based on the clinical signs, presence of the characteristic small white necrotic foci in cotyledons. ELISA test is also used to detect antibodies in fetal and maternal serum. Indirect fluorescent antibody test can be used for fluid collrcted from the fetal thorax or abdomen. Serological examination of dam can be used for diagnosis (Matthews, 2009).

\subsection{Treatment and control}

Combination of sulfamethazine (SMZ) and pyrimethamine (PMA) can be effective in pregnant ewes. The drugs are effective against the proliferating parasites in the acute stage of the disease (Radostits et al., 2008). The combined dose of (SMZ) and (PMA) is administered over 3 days for 3 periods, commencing on days 110, 115 and 130 of gestation. SMZ is injected s.c. at an initial dose of $5 \mathrm{ml} / 10 \mathrm{~kg}$ body wt on the first day of a given treatment priod with subsequent doses of $2.5 \mathrm{ml} / 10 \mathrm{~kg}$ on each of the next 2 days. PMA is administered at $2 \mathrm{mg} / \mathrm{kg}$ on the first day and at $1 \mathrm{mg} / \mathrm{kg}$ on the subsequent 2 days of each treatment period (Buxton et al., 1993).

Because the cats are the only definitive host of toxoplasmosis, it should be kept away from animals farm, and also feeding and drinking water should be prevented from contamination by cat feces. Aborted fetus and excreta, must be strictly disinfected.

It is important to reduce the risk for human disease associated with consumption of infected meat (Radostits et al., 2008).

\section{Tryponosomosis}

\subsection{Etiology}

Member of the genus Trypanosoma are lived in the bloodstream and tissues of cattle, sheep, and goats in all of the world. These are flagellated protozoal agents that produce a variety of very serious disease of human and animals, but many of them are nonpathogenic (Carlson, $2009 \mathrm{~b})$. Trypanosomosis is one of the most important diseases of animals and human. Most African species are transmitted by the tsetse flies (Taylor et al., 2007).

There are 7 species of Trypanosoma species in cattle, sheep, and goat but all of them may not be pathogenic (Table 12).

\begin{tabular}{|l|l|l|}
\hline Specie & Affinity site & Hosts \\
\hline T. brucei brucei & $\begin{array}{l}\text { Blood, myocardium, central } \\
\text { nervous system, } \\
\text { reproductive tract }\end{array}$ & Cattle, sheep, goats,camel \\
\hline T. brucei evansi & Blood & $\begin{array}{l}\text { Cattle, zebu, goats, camel, } \\
\text { deer }\end{array}$ \\
\hline T. congolense & Blood & Cattle, sheep, goats, camel \\
\hline T. vivax & Blood & $\begin{array}{l}\text { Cattle, sheep, goats, camel, } \\
\text { antelope }\end{array}$ \\
\hline T. theileri & Blood & Cattle \\
\hline T. simiae & Blood & Sheep, goats, camel \\
\hline T. melophagium & Blood & Sheep, goats \\
\hline
\end{tabular}

Table 12. Trypanosoma species identified in cattle, sheep, and goats. 


\subsection{Epidemiology}

\subsubsection{African trypanosomosis (Nagana)}

African trypanosomoses caused by T. brucei brucei, T. congolense, T. vivax, and T. simiae, these species affect all domestic mammals and transmitted by tsetse flies.

The most pathogens species in cattle are T. congolense and T. vivax. T. congolense and $\mathrm{T}$. vivax caused severe disease in cattle, sheep, and goat but T. brucei brucei causes a subclinical infection in cattle, and severe disease in sheep, and goat (Radostits et al., 2008). Trypanosoma evansi causes surra disease of cattle in India.

In Ethiopia the prevalence of infection in bovine which is caused by by $\mathrm{T}$. species are reported as below:

T. vivax $90.5 \%$; $\mathrm{T}$. congolence $4 \%$; and mixed infection of $\mathrm{T}$. vivax and $\mathrm{T}$. congolence $5.5 \%$ (Mihret and Mamo, 2007).

T. theileri is nonpathpgeic and reported in Nourth Americabut occasionally occur parasitemia that causes fever, depression, and decreased milk production (Carlson, 2009b).

\subsection{Pathogenesis}

In African Trypanosomosis, after entering through the skin, parasite reach to the bloodstream via the lymphatic system. Infection characterized with parasitemia. Some trypanasoma spp. invade extravascular spaces such as the ocular aqueous humor and cerebral spinal fluid. Some trypanasoma spp. may produce hemolysin that causes anemia in the host. Then, phagocytic activity increased because of the massive erythrocyte failure. (Cebra, C., and Cebra, M., 2002b).

\subsection{Clinical findings}

Clinical findings are based on the speed of onset of anemia and the grade of organ impairment. Trypanasomosis can be acute, subacute, or chronic. In acute form abortion, drop in milk, depression, anorexia can be seen. Hyperemic mucous membranes and lacrimation also can be occur. In subacute form clinical signs include weight loss, enlargement of lymph nodes and dry hair coat. In chronic form dull, dry hair coat, inelastic skin, lethargy, pale mucous membranes and execise intolerance may be seen (Cebra, C., and Cebra, M., 2002b) .

T. theileri rarely causes clinical signs, but sometimes parasitemia may develope (Carlson, 2009b).

\subsection{Diagnosis}

Diagnosis can be based on the clinical findings, presence of vectors, appearance of trypanasomes on a fresh blood smear, or a Giemsa-stained blood smear. Indirect fluorescent antibody test (IFA) and the enzyme-linked immunospecific assay (ELISA) test are used for diagnosis (Cebra, C., and Cebra, M., 2002b) .

\subsection{Treatment and control}

The most common drugs that is used for treatment of trypanosomosis are shown below. 
- $\quad$ Diminazene aceturate 3.5-7 mg/ kg BW.

- Homidium bromide and chloride $1 \mathrm{mg} / \mathrm{kg}$ BW -Pyrithidium bromide $2 \mathrm{mg} / \mathrm{kg}$ BW.

- $\quad$ Isometamidium 0.25-1mg / kg BW (Radostits et al., 2008 ).

Vector control can help to control or prevent trypanosomosis. Insecticides can be used for prevent bites by tsetse flies and other flies (Cebra, C., and Cebra, M., 2002b) .

\section{References}

Allison, R.W., and Meinkoth, J.H., 2010. Anemia Caused by Rickettsia, Mycoplasma, and Protoza. In: Weiss, D.J., and Wardrop, K.J. (Eds): Schalm's Veterinary Hematology. $6^{\text {th }}$ Ed. Wiley- Blackwell.

Antonio Castillo, J., Miguel Marcen, J., Ortega Mora, L. M., and Alvarez Garcia, G., 2009. Bovine besnoitiosis, presented as an emerging disease in Europe. Albeitar (127) Zaragoza: ASIS Veterinaria, 24-25.

Arslan, M.O., and Sari, B., 2010. Eimeridae (Memelilerde Coccidiosis). In: Dumanli, N., and Karaer, Z. (Eds): Veteriner Protozooloji. Medisan Ltd, Turkiye.

Ballweber, L.R., 2009. Coccidiosis in food animals. In: Smith, B.P. (Eds): Large Animal Internal Medicine. Mosby, Elsevier, St. Louis, pp: 1645-1647.

Buxton, D., Thomson, K.M., and Maley, S., 1993. Treatment of ovine toxoplasmosis with a combination of sulphamezathine and pyrimethamine. Veterinary Record. 132 (16), 409-411.

Carlson, G.P., 2009a. Theileriasis. In: Smith, B.P. (Eds): Large Animal Internal Medicine. Mosby, Elsevier, St. Louis, p 1160.

Carlson, G.P., 2009b. Trypanosomiasis. In: Smith, B.P. (Eds): Large Animal Internal Medicine. Mosby, Elsevier, St. Louis, p 1160.

Castro-Hermida, J.A., Gonzalez-Warleta, M., and Mezo, M., 2007. Natural infection by Cryptosporidium parvum and Giardia duodenalis in sheep and goats in Galicia (NW Spain). Small Ruminant Research. 72, 96-100.

Cebra, C., and Cebra, M., 2002a. Diseases of the Hematologic, Immunologic, and Lymphatic Systems (Multisystem Diseases). In: Pugh, D.G. (Eds): Sheep and Goat Medicine. Saunders, An Imprint of Elsevier. Philadelphia, Pennsylvania.

Cebra, C., and Cebra, M., 2002b. Diseases of the Cardiovascular System. In: Pugh, D.G. (Eds): Sheep and Goat Medicine. Saunders, An Imprint of Elsevier. Philadelphia, Pennsylvania.

Christensen, B.W., Drost, M., Troedsson, M.H.T., 2009. Female reproductive disorders. In: Smith, B.P. (Eds): Large Animal Internal Medicine. Mosby, Elsevier, St. Louis, pp: 1419-1469.

Dubey, J.P., Buxton, D., and Wouda, W., 2006. Pathogenesis of bovine neosporosis. Journal of Comparative Pathology. 134 (4), 267-289.

Dubey, J.P., Lindsay, D.S., and Speer, C.A., 1998. Structure of Toxoplasma gondii tachyzoites, bradyzoites and sporozoites, and biology and development of tissue cysts. Clinical Microbiology Reviews 11, 267-299.

El- Khodery, S.A., and Osman, S.A., 2008. Cryptosporidiosis in buffalo calves (Bubalus bubalis): prevalence and potential risk factors. Tropical Animals Health and Production. 40(6), 419-426. 
Feitosa, F.L.F., Shimamura, G.M., Roberto, T., Mendes, L.C.N., Peiro, J.R., Feres, F.C., Bovino, F., Perri, S.H.V., and Meireles, M.V., 2008. Importance of Cryptosporidium spp. As a cause of diarrhea in calves. Pesquisa Veterinaria Brasileira. 28(10), 452456.

Geurden, T., Claerebout, E., Dursin, L., Deflandre, A., Bernay, F., Kaltsatos, V., and Vercruysse, J., 2006. The efficacy of an oral treatment with paromomycin against an experimental infection with Giardia in calves. Veterinary Parasitology. 135, 241247.

Ghanem, M.M., Radwaan, M.E., Moustafa, A.M.M., and Ebeid, M.H., 2008. Comparative therapeutic effect of toltrazuril, sulphadimine and amprolium on Eimeria bovis and Eimeria zuernii given at different times following infection in buffalo calves (Bubalus bubalis). Preventive Veterinary Medicine. 84, 161-170.

Gumber, S., Aradhana, Sharma, D.R., and Singh, J., 2002. Neosporosis- an emerging cause of bovine abortion- a review. Veterinary Practitioner. 3(2), 94-100.

Gunn, A.A., Naylor, J.A., and House, J.K., 2009. Diarrhea. In: Smith, B.P. (Eds): Large Animal Internal Medicine. Mosby, Elsevier, St. Louis, pp: 340- 363.

Hill, D.E., Sreekumar, C., Dubey, J.P., 2002. Toxoplasma gondii. In: Friend, M., Brand, C.J. (Eds.), Field Manual of Wildlife Zoonosis. USGS National Wildlife Health Center, Madison, WI, pp. 357-382.

Hunter, P.R., and Thompson, R.C.A., 2005. The zoonotic transmission of Giardia and Cryptosporidium. International Journal of Parasitology. 35, 1181-1190.

Inci, A., Ica, A., Yildirim, A., and Duzlu, O., 2010. Identification of Babesia and Theileria species in small ruminants in Central Anatolia (Turkey) via reverse line blotting. Turkish Journal of Veterinary Science. 34(2): 205-210.

Jacquiet, P., Lienard, E., and Franc, M., 2010. Bovine besnoitiosis: epidemiological and clinical aspects. In: Franc, M., Kramer, L., and Jacobs, D. (Eds): Veterinary Parasitology. 174 (1/2) Oxford: Elsevier Ltd, 30-36.

Jammes, C., 2009. Bovine anaplasmosis caused by Anaplasma marginale and bovine babesiosis. The situation in metropolitan France and on the island of Reunion. Bulletin de la Societe Veterinaire Pratique France. 93 (2), 34-41.

Jones, T.C., Hunt, R.D., and King, N.W., 1997. Diseases due to protozoa. In: Veterinary Pathology, Ed. Williams \& Wilkins Company, Pennsylvania, 575-581.

Klein, P., 2008. Preventive and therapeutic efficacy of halofuginone-lactate against Cryptosporidium parvum in spontaneously infected calves: acentralised, randomized, double-blind, placebo-controlled study. Veterinary Journal 177 (3), 429-431.

Lawrence, J.A., 2004. Theileriosis of sheep and goats. In: Coetzer, J.A.W., and Tustin, R.C. (Eds): Infectious diseases of livestock, Volum One 2th Edn, Oxford: Oxford University Press, pp: 498-499.

Lawrence, J.A.W., Perry, B.D., and Williamson, S.M., 2004. Zimbabwe theileriosis. In: Coetzer, J.A.W., and Tustin, R.C. (Eds): Infectious diseases of livestock, Volum One 2th Edn, Oxford: Oxford University Press, pp: 472-474.

Lingli, N., Jianxum, L., Guiquan, G., Miling, M., Zhijie, L., Aihong, L., Zhisheng, D., Jinliang, G., Qiaoyun, R., Youquan, L., Junlong, L., and Hong, Y., 2009. Detection and differentiation of ovine Theileria and Babesia by reverse line blotting in China. Parasitology Research. 104(6), 1417-1423. 
Magona, J.W., Walubengo, J., Olaho-Mukani, W., Jonsson, N.N., Welburn, S.C., and Eisler, M.C., 2010. Clinical features associated with seroconversion to Anaplasma marginale, Babesia bigemina and Theileria parva infections in African cattle under natural tick challenge. Veterinary Parasitology. 171(3-4): 207- 215.

Majzoub, M., Breuer, W., Gollnick, N.S., Rostaher, A., Schares, G., and Hermanns, W., 2010. An outbreak of bovine besnoitiosis in Germany; pathomorphological, ultrastructural and molecular-biological investigations. Wiener Tierarztliche Monatsschrift. 97 (1/2) Wien: BWK Public Relations- Brigitte Weber- Kraus, 9-15.

Matthewa, J., 2009. Abortion. 3th Edn. In: Diseases of the goat.Blackwell Publishing Ltd. Pp: 23- 41.

Melendez, R.D., 2000. Babesiosis: An emerging zoonosis in temperate and tropical zones. a review. Revista Cientifica- Facultad De Ciencias Veterinarias. 10 (1), 13-18.

Mihret, A., Mamo, G., 2007. Bovine trypanosomosis in three districts of East Gojjam zone bordering the Blue Nile River in Ethiopia. Journal of Infection in Developing Countried 1 (3) Sassari: Open Learning on Enteric Pathogens (OLOEP), 321-325.

Miling, M., Jianxum, L., Guiquan, G., Zhijie, L., Youquan, L., Jinliang, G., Aihong, L., Junlong, L., Qiaoyun, R., and Hong, Y., 2009. A serological survey of ovine Theileriosis by ELISA. Chinese Journal of Veterinary Sciences. 29 (12), 1575- 1577.

Nagore, D., Garcia-Sanmartin, J., Garcia-Perez, A.L., Juste, R.A., and Hurtado, A., 2004. Identification, genetic diversity and prevalence of Theileria and Babesia species in a sheep population from Northern Spain. International Journal of Parasitology. 34:1059-1067.

Nambota, A., Samui, K., Sugimoto, C., Kakuta, T., and Onuma, M., 1994. Theileriosis in Zambia: etiology, epidemiology and control measures. Japanese Journal of Veterinary Research. 42 (1), 1-18.

Navarre, C.B., and Pugh, D.G., 2002. Diseases of the Gastrointestinal System. In: Pugh, D.G. (Eds): Sheep and Goat Medicine. Saunders, An Imprint of Elsevier. Philadelphia, Pennsylvania.

Norval, R.A.I., Perry, B.D., Gebreab, F., and Lessard, P., 1991. East coast fever: a problem of the future fort he horn of Africa? Preventive Veterinary Medicine. 10,3, 163-172.

OIE., 2004. Manual of diagnostic tests and vaccines for terrestrial animals, 5th Edn, chapter 2.3.11.

Olson, M.E., Ryan O'Handley, R., Ralston, B., and Thompson, R.C.A., 2004. Emerging issues of Cryptosporidium and Giardia infections in cattle. Trends in Parasitology. 20, 185-191.

Oryan, A., and Azizi, S., 2008. Ultrastructure and pathology of Besnoitia caprae in the naturally infected goats of Kerman, East of Iran. Parasitology Research. 102 (6), 1171-1176.

Osman, S.A., Al-Gaabary, H., 2007. Clinical, haematological and therapeutic study on tropical theileriosis in water buffaloes (Bubalus bubalis) in Egypt. Veterinary Parasitology. 146, 337-340.

Ozer, E., and Saki, C.E., 2001. Turkiye'de Coccidiosis. In: Dincer, S. (Eds): Coccidiosis. Turkiye Parazitoloji Dernegi, Yayin no: 17. Izmir, pp:151-162.

Ozmen, O., Sahinduran, S., and Yukari, B.A., 2004. Comparative evaluation on clinicopathological findings and treatment in acute and chronic Coccidiosis of lambs and kids. Indian Veterinary Journal. 81, 1206-1209. 
Ozmen, O., Sahinduran, S., Haligur, M., Yukari, B.A., and Dorrestein, G.M., 2009. Encephalitic Sarcocystosis and its Prophylactic Treatment in Sheep. Turkish Journal of Veterinary \& Animal Sciences. 33(2): 151-155.

Ozmen, O., Yukari, B.A., Haligur, M., and Sahinduran, S., 2006. Observations and immunohistochemical detection of Coronavirus, Cryptosporidium parvum and Giardia intestinalis in neonatal diarrhea in lambs and kids. Schweizer Archiv Fur Tierheilkunde. 148, 357- 364.

Radostits, O.M., Gay, C.C., Blood, D.C., and Hinchcliff, K.W., 2000. Veterinary Medicine. A Textbook of the Diseases of Cattle, Sheep,Pigs, Goats and Horses, 9th Ed. W.B. Saunders, Philadelphia.

Radostits, O.M., Gay, C.C., Hinchcliff, K.W., and Constable, P.D., 2008. Diseases associated with protozoa. 10th Edn. In: Veterinary Medicine: A Textbook of Diseases of cattle, horses, sheep, pigs, and goats. Saunders Elsevier; pp: 1483-1540.

Rahbari, S., Nabian, S., Khaki, Z., Alidadi, N., and Ashrafihelan, J., 2008. Clinical, haematologic and pathologic aspects of experimental ovine babesiosis in Iran. Iranian Journal of Veterinary Research. 9(1), 59-64.

Reilly, L.K., Baird, A.N., and Pugh, D.G., 2002. Diseases of the Musculoskeletal System. In: Pugh, D.G. (Eds): Sheep and Goat Medicine. Saunders, An Imprint of Elsevier. Philadelphia, Pennsylvania.

Sahinduran, S., Sezer, K., Buyukoglu, T., Yukari, B.A., and Albay, M.K., 2006. Plasma ascorbic acid levels in lambs with coccidiosis. Turkish Journal of Veterinary \& Animal Sciences. 30, 219-221.

Sayın, F., Nalbantoglu, S., Yukari, B.A., Cakmak, A., and Karaer, Z., 2009. Epidemiological studies on sheep and goat Theileria infection. Ankara Universitesi Veteriner Fakultesi Dergisi. 56 (2), 127-129.

Schares, G., and Conraths, F.J., 2007. Neospora caninum as a cause of bovine abortion- news regarding pathogenesis, epidemiology and diagnosis. Praktische Tierarzt. 88 (9) Hannover: Schlütersche Verlagsgesellschaft mbH \& Co. KG, 730-740.

Sevinc, F., 2004. Cryptosporidiosis in ruminants. Veteriner Bilimleri Dergisi, Konya,Turkey. $20(4), 79-84$.

Shuzhen, G., Zhengphu, Y., Guoxue, W., Wenbiao, W., Denglu, M., and Hongde, D., 2002. Epidemiology of ovine theileriosis in Ganan region, Gansu Province, China. Parasitology Research. 88 (Suppl. 1). Berlin: Springer- Verlag, 536-537.

Smith, M.O., George, L.W., 2009. Diseases of the nervous system. In: Smith, B.P. (Eds): Large Animal Internal Medicine. Mosby, Elsevier, St. Louis.

Taylor, M.A., Coop, R.L., and Wall, R.L., 2007. Veterinary Parasitology. Third Edn. Blackwell Publishing.

Thompson, R.C.A., 2004. The zoonotic significance and molecular epidemiology of Giardia and giardiasis. Veterinary Parasitology. 126, 15- 35.

Urquhart, G.M., Armour, J., Duncan, J.L., Dunn, A.M., and Jennings, F.W., 1987. Veterinary Parasitology. Longman Group UK Limited, Essex CM20 2JE, England.

Xiao, L., 1994. Giardia infection in farm animals. Parasitology Today. 10, 436-438.

Xiao, L., and Herd, R.P., 1994. Infection pattern of Cryptosporidium and Giardia in calves. Veterinary Parasitology. 55, 257-262.

Zaugg, J.L., 2009. Babesiosis. In: Smith, B.P. (Eds): Large Animal Internal Medicine. Mosby, Elsevier, St. Louis, p 1157. 


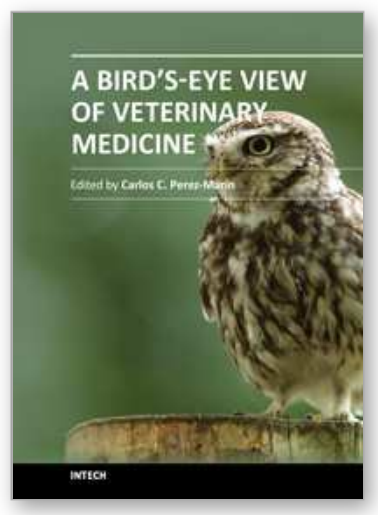

\author{
A Bird's-Eye View of Veterinary Medicine \\ Edited by Dr. Carlos C. Perez-Marin
}

ISBN 978-953-51-0031-7

Hard cover, 626 pages

Publisher InTech

Published online 22, February, 2012

Published in print edition February, 2012

Veterinary medicine is advancing at a very rapid pace, particularly given the breadth of the discipline. This book examines new developments covering a wide range of issues from health and welfare in livestock, pets, and wild animals to public health supervision and biomedical research. As well as containing reviews offering fresh insight into specific issues, this book includes a selection of scientific articles which help to chart the advance of this science. The book is divided into several sections. The opening chapters cover the veterinary profession and veterinary science in general, while later chapters look at specific aspects of applied veterinary medicine in pets and in livestock. Finally, research papers are grouped by specialisms with a view to exploring progress in areas such as organ transplantation, therapeutic use of natural substances, and the use of new diagnostic techniques for disease control. This book was produced during World Veterinary Year 2011, which marked the 250th anniversary of the veterinary profession. It provides a fittingly concise and enjoyable overview of the whole science of veterinary medicine.

\title{
How to reference
}

In order to correctly reference this scholarly work, feel free to copy and paste the following:

Sima Sahinduran (2012). Protozoan Diseases in Farm Ruminants, A Bird's-Eye View of Veterinary Medicine, Dr. Carlos C. Perez-Marin (Ed.), ISBN: 978-953-51-0031-7, InTech, Available from:

http://www.intechopen.com/books/a-bird-s-eye-view-of-veterinary-medicine/protozoan-diseases-in-farmruminants

\section{INTECH}

open science | open minds

\section{InTech Europe}

University Campus STeP Ri

Slavka Krautzeka 83/A

51000 Rijeka, Croatia

Phone: +385 (51) 770447

Fax: +385 (51) 686166

www.intechopen.com

\section{InTech China}

Unit 405, Office Block, Hotel Equatorial Shanghai

No.65, Yan An Road (West), Shanghai, 200040, China

中国上海市延安西路65号上海国际贵都大饭店办公楼 405 单元

Phone: +86-21-62489820

Fax: $+86-21-62489821$ 
(C) 2012 The Author(s). Licensee IntechOpen. This is an open access article distributed under the terms of the Creative Commons Attribution 3.0 License, which permits unrestricted use, distribution, and reproduction in any medium, provided the original work is properly cited. 